\title{
Knowledge about HIV/AIDS and Its Determinants among Assiut University Students, Egypt
}

\author{
Mahmoud A. Abd El Aty and Mirette M. Aziz
}

Public Health \& Community Medicine Department, Faculty of Medicine, Assiut University, Egypt

Received: July, 2018 Accepted: September, 2018

\section{Abstract:}

Background: HIV/AIDS is highly prevalent among youth. Inadequate knowledge and major misconceptions related to HIV/AIDS among adolescents/youth including university students would increase its transmission. Objective: to assess knowledge about HIV/AIDS and its determinants among Assiut University students. Method: A cross-sectional study was carried out on a representative sample of 776 students in Assiut University. A multistage stratified cluster sampling technique was used. A self-administered questionnaire was used to collect data. HIV/AIDs knowledge was assessed and a knowledge score was calculated. Results: Only $70.5 \%$ of Assiut University students have heard about AIDS. The main sources of the students' knowledge were media (46.3\%), internet (44.6\%), school (28\%), university educational courses and health education sessions (27.8\%), friends (23.9\%) and family (22.5\%). The students in the study had a low knowledge score of 35 percent. Some misconceptions about transmission were observed such as AIDS transmission by mosquito bite $(30 \%)$, hugging (19\%), eating with infected person $(17.5 \%)$ or being a hereditary disease (16\%). Only $18 \%$ know that condoms would protect from HIV infection and $28 \%$ knew that patients could look normal without symptoms. Only $45.2 \%$ of the students knew HIV testing site. By applying Logistic regression analysis, the predictors of higher knowledge score about HIV/AIDS were being a medical faculty student, higher (fourth) grade, urban residence and family/university as sources of information. Conclusion and recommendation: University students AIDS related knowledge is inadequate. Efforts should be directed to approach the youth families and youth residing in rural areas and raising their awareness.

Key words: HIV/AIDS, Assiut, Knowledge, Egypt

Corresponding author: Mahmoud Attia Abd El Aty E-mail: mateya2003@yahoo.com

\section{Introduction}

HIV/AIDS is a world challenge; in 2017, an estimated 36.9 million people worldwide were living with HIV, 1.8 million were newly infected and another 940,000 died from AIDS-related illnesses. While $75 \%$ of people with HIV knew their status, only $59 \%$ were accessing treatment. The vast majority of people living with HIV is in low- and middle-income countries and is young and adolescent girls. ${ }^{1}$

Globally, HIV is prevalent (2.1 million) among adolescents (aged 10-19). In 2016, 610,000 young people aged 15-24 were newly infected with HIV, of whom 260,000 were adolescents aged15-19, with $30 \%$ increase in prevalence since the year 2005. ${ }^{2,3}$ Adolescents and young people

$\begin{array}{lllll}\text { The Egyptian Journal of Community Medicine } & \text { Vol. } 37 & \text { No. } 3 & \text { July } & 2019\end{array}$ 
including university students are among the most vulnerable and affected groups by HIV/AIDS, as they pass through the peak period for sexual activity and experimentation..$^{4-6}$

UNICEF projections estimate that without urgent action, leadership support, financing, adolescent engagement, social changes, quality and innovative programs, new adolescent infections will increase in the next decade by $13 \%$ annually reaching 3.5 million new adolescent infections by 2030. Therefore, UN established "ALL IN" initiative targeted through "Fast-Track efforts" towards ending the AIDS epidemic among adolescents and key populations by $2030 .^{2-4}$

In Egypt, an estimated 11,000 adults aged 15 and above were living with HIV in 2016, with concentrated epidemics in key risk groups. Since 2017, Egypt has totally funded domestic treatment for people living with HIV and the "Test and Treat" approach in dispensing treatment. Moreover, large scale media advocacy campaigns were implemented to reach over 2 million social media users and awareness campaigns were directed to university students. ${ }^{2,7}$

Despite the protective conservative cultural and religious factors which contributed in slowing and limiting HIV transmission in MENA region ${ }^{8}$, new HIV infections have increased by $31 \%$ since $2001 .{ }^{9}$ Misconceptions and stigma among the general population may hinder the utilization of counseling and screening services which increase and accelerate the rate of the transmission of AIDS. ${ }^{10}$ The very limited pre-marital and antenatal examinations, weak health system, and the delay of marriage may also place countries including Egypt at risk of a broader epidemic. ${ }^{11-14}$

Lack of knowledge and extensive levels of misconceptions about HIV/AIDS were previously observed in Egypt among the general population and vulnerable groups including women, adolescents/youth, highrisk behavior groups and even health workers. ${ }^{7,8,11,15,16}$

In order to develop a tailored and targeted intervention for prevention of HIV/AIDS among youth, we aimed to explore the level of HIV/AIDS knowledge of the University students; as they are youth of different ages, sex, sociocultural backgrounds, and educational domains and to identify determinants of their knowledge.

\section{Method}

This is a cross-sectional study. Egyptian Students in Assiut University were the target population. Sample design: Target students were selected randomly by using a multistage stratified cluster sampling technique.

At the first stage, Faculties within Assiut University was stratified into 3 strata; Theoretical, Practical, and Medical (then 2 faculties were chosen randomly from each stratum and ended up with 6 faculties; two medicals "Faculty of Medicine, Veterinary", two practicals "Faculty of Engineering and Faculty of Agriculture", and two theoretical "Faculty of Commerce and Faculty of Social Service". In the second stage, students within each faculty were stratified into 2 strata (first\& fourth scholastic year). In the third stage a cluster sample was chosen from each scholastic year within each faculty (practical sections or small classes). The clusters were chosen through simple random sample. Sample size: Sample size was calculated using Epi- Info, version 7. Based on previous study conducted in Assiut ${ }^{17}$ which found that $(30.8 \%)$ of youth in secondary technical schools had satisfactory knowledge about HIV /AIDS. With a confidence level of 95\%, acceptable Table 
(1): Socio-demographic characteristic of the study participants (2016/2017):

\begin{tabular}{|l|l|l|}
\hline & $\mathrm{N}$ & $\%$ \\
\hline Faculty & & \\
\hline Medicine & 100 & 12.9 \\
\hline Veterinary Medicine & 81 & 10.4 \\
\hline Agriculture & 136 & 17.5 \\
\hline Engineering & 106 & 13.7 \\
\hline Commerce & 212 & 27.3 \\
\hline Social service & 141 & 18.2 \\
\hline Grade & & \\
\hline First grade & 376 & 48.5 \\
\hline Fourth grade & 400 & 51.5 \\
\hline Age & & \\
\hline First grade & $\mathbf{1 8 . 9 4}$ & $\mathbf{1 . 0 8}$ \\
\hline Fourth grade & $\mathbf{2 1 . 7 7}$ & $\mathbf{0 . 9 6}$ \\
\hline Sex & & \\
\hline Male & 386 & 49.7 \\
\hline Female & 390 & 50.3 \\
\hline Residence_Governorate* & & \\
\hline Assiut & 474 & 75.7 \\
\hline Sohag & 152 & 24.3 \\
\hline Residence_Urban/rural* & & \\
\hline Urban & 264 & 42.7 \\
\hline Rural & 354 & 57.3 \\
\hline Co-residence with the family & & \\
\hline Yes & 394 & 49.2 \\
\hline No & 382 & 50.8 \\
\hline Students' fathers education* & & \\
\hline Illiterate & 40 & 5.4 \\
\hline Below secondary & 167 & 22.4 \\
\hline Secondary and above & 538 & 72.2 \\
\hline $\begin{array}{l}\text { Students } \\
\text { education* }\end{array}$ & 59 & 7.9 \\
\hline Illiterate & 238 & 32.0 \\
\hline Below secondary & 447 & 60.1 \\
\hline Secondary and above & \\
\hline & & \\
\hline missingal & & \\
\hline
\end{tabular}

*Missing data

margin of error of $3 \%$ and a design effect of 1.2, the sample was estimated to be 1091students. We increased the sample size to 1200 to compensate for the drop out/incomplete questionnaires. The sample was distributed proportionally between the selected faculties. However, out of the distributed 1200 questionnaire, we only obtained 776 completed questionnaires, with a response rate of $64.7 \%$. We omitted all the incomplete ones.

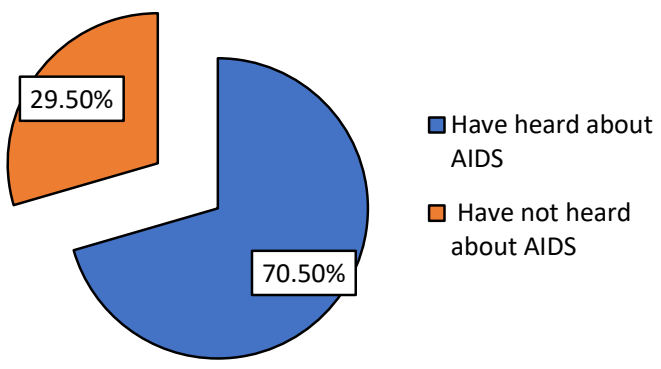

Figure (1): Frequency of Assiut University students who have ever heard about HIV/AIDS

Data collection tool and technique: Data were collected through a self-administered questionnaire. The questionnaire included two modules; socio-demographic module about social and demographic factors of the student and their families and sexual/reproductive health module, guided by EDHS questions, to identify the level of knowledge about sexually transmitted diseases (STDs), specifically HIV/AIDs (cause, modes of transmission, protection, symptoms, screening sites of HIV/AIDs). Each question or statement had three options, namely "Yes, No, Don't know". Before data collection, a pilot study was conducted on 50 university students in different faculties. The pilot data were not included in the analysis.

Data management and statistical analysis: Data management including data entry, cleaning and statistical analysis were done by using IBM SPSS software, version 21.0. Descriptive statistics of the study sample was performed in the form of frequencies to describe the sample characteristics and knowledge about AIDS. HIV/AIDS knowledge score was 
calculated using 12 questions. A score of

"1" was given to each correct answer and a

Table (2): Knowledge of Assiut University students about HIV/AIDs (2016/2017):

\begin{tabular}{|c|c|c|c|c|c|c|}
\hline Students' Knowledge about HIV/AIDs & \multicolumn{2}{|l|}{ Yes } & \multicolumn{2}{|l|}{ No } & \multicolumn{2}{|c|}{ Don't know } \\
\hline Knowledge about AIDs* & $\mathbf{N}$ & $\%$ & $\mathbf{N}$ & $\%$ & $\mathbf{N}$ & $\%$ \\
\hline $\begin{array}{lcc}\text { AIDs is caused by } & \text { Human } \\
\text { immunodeficiency virus } & \text { (HIV) }\end{array}$ & 399 & 60.1 & 25 & 3.8 & 240 & 36.1 \\
\hline AIDs is a sexually transmitted disease & 512 & 71.4 & 24 & 3.3 & 181 & 25.2 \\
\hline \multicolumn{7}{|l|}{ AIDs is transmitted by: } \\
\hline - Hugging an infected person & 103 & 15.1 & 233 & 34.2 & 345 & $\mathbf{5 0 . 7}$ \\
\hline - Eating with infected person & 119 & $\mathbf{1 7 . 5}$ & 219 & 32.2 & 343 & 50.4 \\
\hline - Blood transfusion & 413 & 59.5 & 45 & 6.5 & 236 & 34.0 \\
\hline - Infected needles & 405 & 58.1 & 37 & 5.3 & 255 & 36.6 \\
\hline - Mosquito bite & 206 & 30.2 & 123 & 18.0 & 353 & 51.8 \\
\hline - Genetic disease & 108 & $\mathbf{1 5 . 8}$ & 22.3 & 32.6 & 354 & 51.7 \\
\hline - From mother to child & 218 & 31.6 & 95 & 13.8 & 376 & 54.7 \\
\hline $\begin{array}{l}\text { Using condoms would protect from HIV } \\
\text { infection }\end{array}$ & 127 & 18.4 & 93 & $\mathbf{1 3 . 5}$ & 471 & 68.2 \\
\hline $\begin{array}{l}\text { Using combined oral contraceptives } \\
\text { would protect from HIV infection }\end{array}$ & 43 & 6.2 & 191 & 27.9 & 459 & 66.2 \\
\hline $\begin{array}{l}\text { AIDs patients could have no manifest } \\
\text { symptoms }\end{array}$ & 196 & 27.7 & 146 & 20.6 & 366 & 51.7 \\
\hline AIDS knowledge score & \multicolumn{6}{|c|}{$4.20 \pm 3.35$} \\
\hline AIDS knowledge score percent & \multicolumn{6}{|c|}{$35.00 \pm 27.93$} \\
\hline
\end{tabular}

*All variables had missing data

score of " 0 " to the false and "don't know"

responses. All scores were summed and the mean score was calculated. The mean score percent was calculated by dividing the mean score by 12 (The maximum score if all questions were correctly answered). The relationships between AIDS knowledge scores and studied variables were done by proper statistical test (Students't-test, and F- test). All significant variables with a $\mathrm{p}$ value $<0.05$ on bivariate analysis were considered for inclusion in multivariate linear regression models. In all statistical tests used, statistical difference considered significant when P-value was less than 0.05 .

Ethical consideration:

The proposal was approved by the Ethical Review Committee of Assiut Faculty of Medicine before starting data collection; IRB number 00008718. Written informed consent was obtained from participating students (at the first page of the

questionnaire). Administrative permissions were obtained from the higher authorities of the University and selected faculties.

\section{Results}

Table (1) shows the socio-demographic characteristics of the study participants. Almost half of the study participants were males $(49.7 \%)$. The participants were mainly from two governorates in Upper Egypt; Assiut and Sohag. There was a larger proportion of rural students $(57.3 \%)$ than urban students $(42.7 \%)$. Almost half of the students $(49.2 \%)$ were residing with their families during the educational year. The table also shows that the students were nearly equally distributed between the first $(48.5 \%)$ and fourth grades $(51.5 \%)$. A large proportion of the students' parents had secondary and higher levels of education (72.2\% of fathers and $60.1 \%$ of mothers).

It was found that only $(70.1 \%)$ of Assiut University students have ever heard about 
AIDS (Figure 1). Regarding the source of their knowledge, they mainly obtained Table (3): Factors affecting HIV/AIDS knowledge among Assiut University students (2016/2017):

\begin{tabular}{|c|c|c|c|}
\hline Variables & Mean \pm SD & $\begin{array}{l}\text { Test of } \\
\text { significance }\end{array}$ & P-value \\
\hline \multicolumn{4}{|l|}{ Sex: } \\
\hline Male & $4.21 \pm 3.62$ & \multirow{2}{*}{$t=-721$} & \multirow{2}{*}{0.471} \\
\hline Female & $4.39 \pm 3.09$ & & \\
\hline \multicolumn{4}{|l|}{ Faculty: } \\
\hline Medical & $7.00 \pm 3.11$ & \multirow[t]{3}{*}{$F=49.35$} & \multirow[t]{3}{*}{$<0.001$} \\
\hline Practical & $4.34 \pm 3.24$ & & \\
\hline Theoretical & $4.38 \pm 2.79$ & & \\
\hline \multicolumn{4}{|l|}{ Grade: } \\
\hline First year & $3.38 \pm 2.98$ & \multirow{2}{*}{$t=-6.77$} & \multirow{2}{*}{$<0.001$} \\
\hline Fourth year & $4.97 \pm 3.50$ & & \\
\hline \multicolumn{4}{|l|}{ Residence: } \\
\hline Urban & $5.09 \pm 3.38$ & \multirow[t]{2}{*}{$t=5.05$} & \multirow[t]{2}{*}{$<0.001$} \\
\hline Rural & $4.75 \pm 3.14$ & & \\
\hline \multicolumn{4}{|l|}{ Co-residence with the family: } \\
\hline Yes & $4.47 \pm 3.32$ & \multirow[t]{2}{*}{$t=2.305$} & \multirow[t]{2}{*}{0.021} \\
\hline No & $3.92 \pm 3.36$ & & \\
\hline \multicolumn{4}{|l|}{ Father's education: } \\
\hline Illiterate & $4.80 \pm 3.63$ & \multirow[t]{3}{*}{$F=4.65$} & \multirow[t]{3}{*}{0.010} \\
\hline Below secondary & $3.56 \pm 2.97$ & & \\
\hline Secondary and above & $4.40 \pm 3.41$ & & \\
\hline \multicolumn{4}{|l|}{ Mother's education: } \\
\hline Illiterate & $4.18 \pm 3.53$ & \multirow[t]{3}{*}{$F=3.138$} & \multirow[t]{3}{*}{0.044} \\
\hline Below secondary & $3.79 \pm 3.16$ & & \\
\hline Secondary and above & $4.46 \pm 3.42$ & & \\
\hline \multicolumn{4}{|l|}{ Source of knowledge_family: } \\
\hline Yes & $5.60 \pm 3.16$ & \multirow[t]{2}{*}{$\mathrm{t}=\mathbf{2 . 0 6 5}$} & \multirow[t]{2}{*}{0.039} \\
\hline No & $4.92 \pm 3.23$ & & \\
\hline Source of knowledge_friends: & & & \\
\hline Yes & $4.98 \pm 3.24$ & $t=-0.367$ & 0.714 \\
\hline No & $5.10 \pm 3.22$ & & \\
\hline Source of knowledge_School: & & & \\
\hline Yes & $5.57 \pm 3.22$ & $\mathrm{t}=2.241$ & $\mathbf{0 . 0 2 5}$ \\
\hline No & $4.88 \pm 3.16$ & & \\
\hline Source of knowledge_University: & & & \\
\hline Yes & $6.46 \pm 3.35$ & $T=6.468$ & $<0.001$ \\
\hline No & $4.54 \pm 3.01$ & & \\
\hline Media*: & & & \\
\hline Yes & $5.39 \pm 3.27$ & $t=2.11$ & $\mathbf{0 . 0 3 5}$ \\
\hline No & $4.81 \pm 3.16$ & & \\
\hline Source of knowledge_Internet: & & & \\
\hline Yes & $5.29 \pm 3.26$ & $t=1.83$ & 0.168 \\
\hline No & $4.90 \pm 3.18$ & & \\
\hline $\begin{array}{lll}\begin{array}{l}\text { Source } \\
\text { services: }\end{array} & \text { of } & \text { knowledge_healthcare** } \\
\end{array}$ & & & \\
\hline Yes & $4.94 \pm 3.39$ & $\mathrm{t}=\mathbf{- 0 . 2 4 9}$ & 0.804 \\
\hline No & $5.08 \pm 3.21$ & & \\
\hline
\end{tabular}

*Media sources include TV, books and magazines

**Health care sources include public and private clinics

$\begin{array}{lllll}\text { The Egyptian Journal of Community Medicine } & \text { Vol. } 37 & \text { No. } 3 & \text { July } & 2019\end{array}$ 
Table (4): Predictors of higher knowledge score about HIV/AIDS among the University students:

\begin{tabular}{|l|l|l|l|l|}
\hline Predictors & $\begin{array}{l}\text { Standardized } \\
\text { B coefficient }\end{array}$ & SE & $\begin{array}{l}\text { Confidence } \\
\text { interval }\end{array}$ & P-value \\
\hline Medical faculties & $\mathbf{- 0 . 2 8 4}$ & $\mathbf{0 . 1 9 3}$ & $-\mathbf{1 . 5 0 1}-\mathbf{- 0 . 7 4 1}$ & $<\mathbf{0 . 0 0 1}$ \\
\hline Higher faculty Grade $\left.\mathbf{4}^{\text {th }}\right)$ & $\mathbf{0 . 2 3 2}$ & $\mathbf{0 . 3 0 4}$ & $\mathbf{0 . 9 1 3}-\mathbf{2 . 1 0 7}$ & $<\mathbf{0 . 0 0 1}$ \\
\hline Urban residence & $\mathbf{- 0 . 0 9 9}$ & $\mathbf{0 . 3 1 7}$ & $-\mathbf{1 . 2 6}--\mathbf{0 . 0 1 3}$ & $\mathbf{0 . 0 4 6}$ \\
\hline C0-residence with family & $\mathbf{0 . 0 3 7}$ & $\mathbf{0 . 2 9 2}$ & $\mathbf{- 0 . 3 3 5}-\mathbf{0 . 8 1 5}$ & $\mathbf{0 . 4 1 3}$ \\
\hline Father's eduaction & $\mathbf{0 . 0 6 6}$ & $\mathbf{0 . 3 2 4}$ & $\mathbf{- 0 . 2 4 2}-\mathbf{1 . 0 3 2}$ & $\mathbf{0 . 2 2 3}$ \\
\hline Mother's education & $\mathbf{- 0 . 0 7 2}$ & $\mathbf{0 . 2 9 1}$ & $\mathbf{- 0 . 9 4 3 - 0 . 2 0 3}$ & $\mathbf{0 . 2 0 5}$ \\
\hline Source of information_family & $\mathbf{0 . 1 2 2}$ & $\mathbf{0 . 3 4 4}$ & $\mathbf{0 . 2 5 3}-\mathbf{1 . 6 0 4}$ & $\mathbf{0 . 0 0 7}$ \\
\hline Source of information_school & $\mathbf{- 0 . 0 5 5}$ & $\mathbf{0 . 3 1 8}$ & $\mathbf{- 0 . 2 3 6 - 1 . 0 1 5}$ & $\mathbf{0 . 2 2 1}$ \\
\hline Source of information_University & $\mathbf{0 . 1 0 1}$ & $\mathbf{0 . 2 8 6}$ & $\mathbf{0 . 0 5 7}-\mathbf{1 . 3 5 6}$ & $\mathbf{0 . 0 3 3}$ \\
\hline Source of information_media & $\mathbf{0 . 3 3 0}$ & $\mathbf{0 . 2 8 6}$ & $\mathbf{- 0 . 5 4 1 - 0 . 5 8 4}$ & $\mathbf{0 . 9 4 0}$ \\
\hline
\end{tabular}

AIDS related knowledge from Media; TV, books and magazines $(46.3 \%)$, internet (44.6\%), school (28\%) and University educational courses/ health education sessions (27.8\%). However, friends $(23.9 \%)$ and family $(22.5 \%)$ represented other sources of information for less than one quarter of the students (Figure 2).

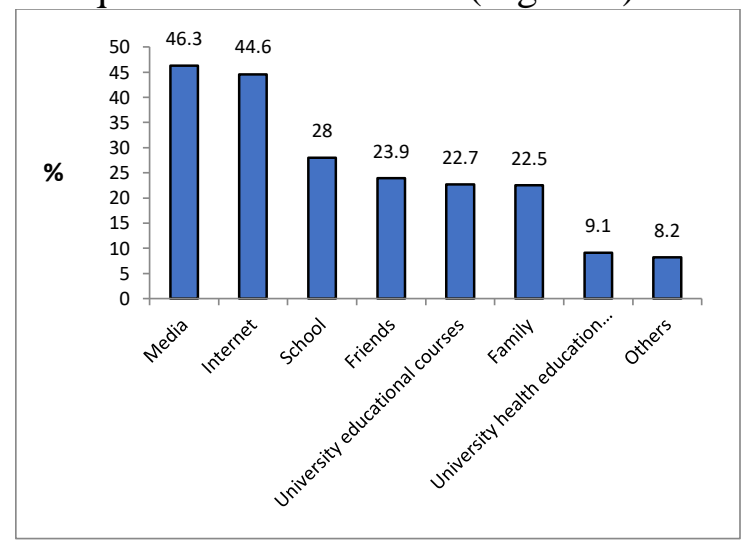

Figure (2): Sources of University students' knowledge about HIV/AIDS (2016/2017)

Table (2) shows the university students' responses to the 12 statements used to assess their level of knowledge about HIV/AIDS. Some statements were correct and others were false. The table shows that only $(60.1 \%)$ of the students knew the causative agent of AIDS. It was also found that large proportions of the students knew that HIV/AIDS is transmitted sexually (71.4\%), by blood transfusion $(59.5 \%)$ and through the use of infected needles
$(58.1 \%)$. However, a much smaller proportion $(31.6 \%)$ knew that it could be transmitted from the mother to child. Surprisingly, only less than one fifth of the students $(18.4 \%)$ knew that condoms could protect against the transmission of HIV/AIDS and only (27.7\%) knew that HIV/AIDS patients could look healthy with no manifest symptoms. The students had a low knowledge mean score percent of $35 \%$.

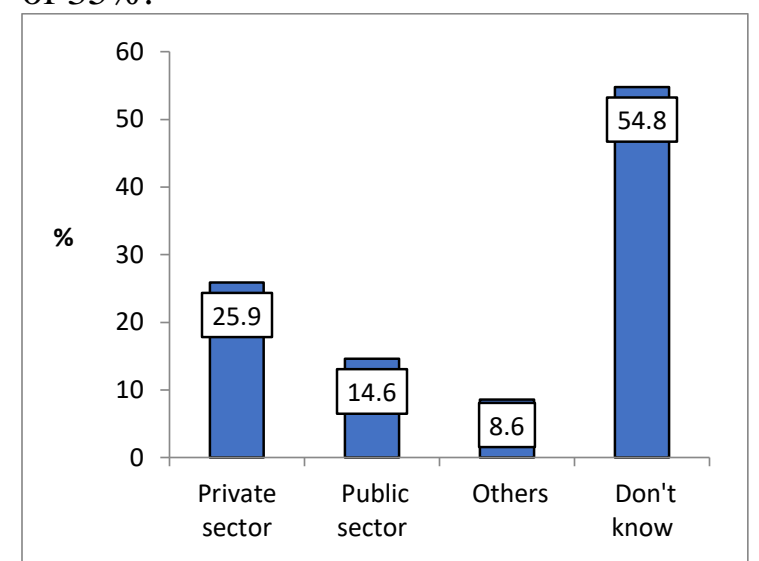

Figure (3): Knowledge of Assiut University students about HIV investigation sites

Tables $3 \& 4$ show the results of the bivariate and multivariate analysis of the factors that could affect the university students' level of knowledge about HIV/AIDS. It was found that students in medical faculties $(B=-0.284, p<0.001)$ and those in the fourth grade $(B=0.232, P$ 
$<0.001)$ had higher HIV/AIDS knowledge score. Moreover, urban students $(\mathrm{B}=$ $0.099, \mathrm{p}<0.05)$ had better level of knowledge than their rural counterparts. Also, obtaining information from the family $(\mathrm{B}=0.122, \mathrm{p}<0.01)$ and the university $(B=0.101, p<0.05)$ were significantly associated with better knowledge.

Figure 3 shows that more than half of the University students (54.8\%) who have heard about AIDS didn't know the available investigations sites. About a quarter of them $(25.9 \%)$ mentioned the private sector compared to only (14.6\%) who mentioned public sector.as their known sites for AIDS investigations.

\section{Discussion}

Adolescence is the period when young people begin to explore their sexuality; as a result, access to sexual and reproductive health information and services becomes increasingly important. Correct knowledge will help them to overcome fear, denial and also contribute to behavior modification to reduce new HIV infections. ${ }^{6,18}$

Recently, global targets of reducing new HIV infections among adolescents by $75 \%$ and AIDS-related deaths by $65 \%$ have emerged. The global "All In" strategic framework aligns with the vision of zero new HIV infections, zero AIDS-related deaths and zero discrimination that will end the epidemic among adolescents (1019 y) by $2030.4,7$

As HIV/AIDS is highly prevalent among youth who represent an important vulnerable group and as they are the targeted focus of interventions directed towards elimination of infection, we aimed in this study to explore their level of AIDS related knowledge and the factors that predict their better knowledge. Identifying the youth knowledge gaps would help to develop a tailored health promotion initiative based on their needs.

Poor knowledge about AIDS among youth has been documented by previous studies conducted in Egypt. The survey of young people in Egypt (SYPE) which was conducted on a national sample of 10,916 Egyptian adolescents and young population aged 13-35 found that only $73.2 \%$ of respondents knew HIV/AIDS, and only 35\% know 3-4 modes of transmission. Moreover, only $17.1 \%$ of respondents were found to be willing to interact with someone living with HIV/AIDS, which reflected the misconceptions they had about the possible modes of transmission. Similarly, respondents of SYPE have mentioned insect bite and sharing food as false methods of AIDS transmission. ${ }^{15}$

Moreover, youth poor knowledge about HIV/AIDS has also been documented in Egypt Health Issue Survey 2015, where comprehensive AIDS knowledge was found to be very limited among adolescents/youth aged 15-24 (4\% of women and $7 \%$ of men). ${ }^{19}$

Also, an earlier study conducted on Suez Canal university students to assess awareness and practice of health risky behavior found that only $66 \%$ of students had adequate knowledge about AIDS and $61.5 \%$ of those who had sexual relationships did not use any method of protection from STDs. ${ }^{20}$

On the other hand, nursing students in Cairo University ${ }^{[21]}$ seemed to know the correct ways of HIV transmission, especially the infected blood, the shared syringes and sharps. This was supported by an Indian study on nursing students which revealed an overall adequate level of knowledge. ${ }^{22}$

Poor adolescents and young adult's knowledge about AIDS were not only documented in Egypt but also in other developing countries, such as in sub- 
Saharan Africa, as only $26 \%$ of adolescent girls aged 15-19 years and 36\% of adolescent boys had a comprehensive and correct knowledge of HIV. ${ }^{5}$

On the contrary, University students in other developing countries have shown good level of knowledge about AIDS, as $97.1 \%$ of the Nigerian University students were found to have good AIDS related knowledge. $^{23}$ Also, in three African universities located in Kenya, South Africa and Tanzania, the majority of participant students were highly knowledgeable about HIV/AIDS transmission, infection and prevention. ${ }^{24}$ The good knowledge of the students has been attributed to the sustained governmental efforts directed to raise the health awareness of youth and establishment of youth clubs aiming to train university students to provide peer education in their respective campuses. ${ }^{23}$ Poor knowledge and misconceptions about the HIV/AIDs is dangerously alarming as it may hinder acceptability and access to key services such as; counseling, screening and treatment ${ }^{[25]}$. As a result of lack of comprehensive knowledge on how to avoid HIV infection, many of both young women and men continue to get infected. ${ }^{26}$ However, it should be noted that awareness alone is not adequate for changing behavior and prevention of HIV/ AIDS, as in Nigeria, despite the good knowledge of adolescents about the modes of contracting and transmitting HIV/AIDS, high-risk sexual behavior (non-use of condom and having multiple sexual partners) was highly observed. ${ }^{18,27}$

It was found that Assiut University students mainly obtained knowledge about AIDS from media $(46.3 \%)$ and internet $(44.6 \%)$. Consistent with our findings, media was the most frequently mentioned source of information about AIDS by SYPE respondents (60.9\%) [15] In Suez Canal university, the main sources of students' knowledge were also media
(38\%) followed by friends $(30 \%){ }^{20}$ Also, $\mathrm{TV}$ was the main source of information $(66.7 \%)$ for nursing students in Cairo University. ${ }^{21}$

The university, whether through the educational courses or the conducted health awareness sessions, represented a considerable source of information for almost one third (27.8\%) of students who knew about AIDS. Moreover, students who obtained their AIDS related information from the university had significantly better knowledge about AIDS than those who obtained information from other sources, which highlights the importance of the university as a professional and trusted source of information directed to youth.

Consistent with previous studies $^{28,29}$, family was observed to be a less frequent source of information about HIV/AIDS; as it was the source of information for only $(22.5 \%)$ of students. This could be attributed to the embarrassment in discussing sex and sexuality with their parents, and feeling more comfortable discussing the same issues with their friends. ${ }^{29}$ However, in this study, despite being a less frequent source of information, students who obtained their information from the family significantly had better level of knowledge by logistic regression analysis.

Despite the negligible role of health care providers as source of knowledge of the University students in our study, their role was evident as an important source of information to the first-year students in Marmara University, Turkey ${ }^{30}$ and the nursing students in India. ${ }^{22}$

In this study, more than half of the university students who have heard about AIDS didn't know the HIV investigations sites, which is contrary to the findings in other high prevalent countries such as Ghana $^{28}$ and Nigeria ${ }^{23}$, where most of the students knew where to access Voluntary

No. 3

July

2019 
Counselling and Treatment services, however the majority had not tested for HIV.

The results of the multivariate analysis showed also that being students in medical faculties and in higher educational grade predicted better level of AIDS knowledge. Moreover, urban students had better knowledge than their rural counterparts.

These findings were consistent with previous studies, as students who were enrolled in health science departments had almost three times more knowledge than those who studied non-health science [31]. However, In Menoufia University, unexpectedly, the knowledge of medical students in the last 3 academic years about STD/AIDs was unsatisfactory, despite their specialized educational courses. ${ }^{32}$

Also, previous studies have documented that students in higher grades of university education showed higher knowledge scores as compared to students in lower faculty grades. ${ }^{2,33}$ Moreover, the low level of knowledge in the first year of university education was previously documented in Marmara University, Turkey, as only $16 \%$ of the first-year students were found to have adequate education about STDs. ${ }^{30}$

Similar to our findings, better HIV/AIDS knowledge among urban youth than rural youth was previously documented by the Egypt Health Issue Survey $2015^{19}$ and EDHS 2014. Moreover, the significant effect of urban residence on higher level of knowledge about AIDS was previously documented in other studies among Chinese college students ${ }^{34}$, and among Nigerian students. ${ }^{35}$ On the other hand, in Menoufia University, there was a nonsignificant difference in the level of knowledge about STD/AIDs between urban and rural students. ${ }^{32}$

Gender was found to have insignificant effect on the level of knowledge about HIV/AIDS in our study and also previous studies in Egypt and other developing countries. $^{32,35}$ On the contrary, other studies recorded better knowledge of male students. ${ }^{5,27}$

\section{Conclusion and Recommendation:}

This study has revealed that youth knowledge about HIV/AIDS is insufficient with prevailing misconceptions. Information, education and communication are required to raise awareness and combating misconceptions. Youth should be approached to increase their correct knowledge about HIV/AIDS through related sectors, such as through education and primary health care in order to reach the target of $90 \%$ of young people/adolescents having the skills, knowledge and capacity to protect themselves from HIV. ${ }^{7}$

The role of university as an important source of raising awareness of the university students should be activated by including AIDS related topics into the curriculum and conducting counseling and health awareness sessions especially in non-medical faculties. Also, efforts should be directed to approach the youth residing in rural areas and youth families to raise their awareness.

Funding: financial support was provided by Faculty of Medicine Grants Unit, Assiut University, as a part of "Health Life Style among Assiut University Students" project fund. (IRB number for the project: IRB 00008718).

Acknowledgements: We would like to thank Assiut University Vice President for Education, the authorities of the selected faculties and the participated students.

Conflicts of interest: The authors declare that there are no conflicts of interest.

\section{References}

1. UNAIDS, 2018: Fact Sheet. Global HIV Statistics, 2017. Available at: http://www.unaids.org/sites/default/files/media 
_asset/UNAIDS_FactSheet_en.pdf. Accessed july 2018

2. UNICEF, 2017: Children and AIDs: Statistical update, December 2017. Available at: www.childrenandaids.org.

3. UNAIDS, 2017: Ending AIDS: Progress towards 90-90-90 targets' Geneva: Joint United Nations Program on HIV/AIDS. Available at: http://www.unaids.org/en/resources/campaigns /globalAIDSupdate2017

4. UNAID and UNICEF,2016:"ALL IN" to end the adolescent AIDs epidemic. A Progress report. Geneva: Joint United Nations Program on HIV/AIDS. Available at: http: //www.unaids.org/sites/default/files/media_a sset/ALLIN2016ProgressReport_en.pdf

5. Idele P, Gillespie A, Porth T, Suzuki C, Mahy M, Kasedde S and Luo C,2014: Epidemiology of HIV and AIDS Among Adolescents: Current Status, Inequities and Data Gaps. J Acquir Immune Defic Syndr 2014; 66 (2).

6. Kirby D ,CoyleK, Rolleri L, Alton Land Robin L. Reducing Adolescent Sexual Risk; A Theoretical Guide for Developing and Adapting Curriculum-Based Programs, 2011.

7. Global AIDS Monitoring, 2018: Country progress report-Egypt: Available at: http: //www.unaids.org/sites/default/files/country/do cuments/EGY_2018_countryreport.pdf.

8. Abu-Raddad LJ, Hilmi N, Mumtaz G, Benkirane M, Akala FA, Riedner G, Tawil O, Wilson D. 2010: Epidemiology of HIV infection in the Middle East and North Africa. AIDS. 2010; 24(2):S5-23.

9. Go"kengin D, Doroudib F, Tohme J, Collins B, Madani N., 2016: HIV/AIDS: trends in the Middle East and North Africa region. International Journal of Infectious Diseases 2016; 44: 66-73.

10. Kabbash IA, Abo Ali EA, Elgendy MM, Mostafa M, Abdrabo MM, Salem HM, Gouda MR, Elbasiony YS, ElboshyN, HamedM.,2016:"HIV/AIDS-related stigma and discrimination among health care workers at Tanta University Hospitals, Egypt". Environmental Science and Pollution Research 2016: 1-8.
11. Zidan OO, Abo Alwafa HO, Ayad WA.,2017: Perception and Practices of Female Sex Workers towards Sexually Transmitted Infections in Greater Cairo, Egypt. The Egyptian Journal of Community Medicine 2017; 35 (4): 35.

12. Kabbash IA, Abdul-Rahman I, Shehata Y, Omar A. HIV infection and related risk behaviours among female sex workers in greater Cairo, Egypt. EMHJ 2012; 18 (9):92027.

13. Kabbash IA, Abdul-Rahman I, Shehata Y. Looking beyond legality: understanding the context of female sex workers in greater Cairo, Egypt. EMHJ 2013; 19 (1):24-29.

14. Petersen Z, Myers B, Hout MC, Plüddemann A, Parry C. Availability of HIV prevention and treatment services for people who inject drugs: findings from 21 countries. Harm Reduction Journal 2013, 10:13.

15. Roushdy R. Sieverding M. Panel Survey of Young People in Egypt (SYPE): Generating Evidence for Policy and Programs. Cairo, Egypt: Population Council, 2015.

16. EDHS. El-Zanaty and Associates [Egypt], and ICF International. Egypt Demographic and Health Survey 2014. Cairo, Egypt and Rockville, Maryland, USA: Ministry of Health and Population and ICF International, 2015.

17. Selim ME, El-Shereef EA. Perceptions of secondary technical school students in Assiut, Upper Egypt, about AIDS: Effect of an educational intervention. J Family Community Med 2010; 17(1): 3-10.

18. Odu, BK, Akanle FF. Knowledge of HIV/AIDS and sexual behavior among the youths in South West Nigeria. International Journal of Tropical Medicine 2008; 3: 79-84.

19. Ministry of Health and Population [Egypt], El-Zanaty and Associates [Egypt], and ICF International 2015. Egypt Health Issue Survey 2015. Cairo, Egypt and Rockville, Maryland, USA: Ministry of Health and Population and ICF international.

20. Refaat A. Practice and awareness of health risk behavior among Egyptian university students. EMHJ 2004; 10 (1-2): 7281. 
21. Taher M, Abdelhai R. Nurses' knowledge, perceptions, and attitudes towards HIV/AIDS: Effects of a health education intervention on two nursing groups in Cairo University, Egypt. Journal of Public Health and Epidemiology 2011; 3 (4): 144-154.

22. DharmalingamM, Poreddi V, Gandhi $S$, Chandra R. Under graduate nursing students' knowledge and attitude toward people living with human immunodeficiency virus/acquired immunodeficiency syndrome. International Journal of Advanced Medical and Health Research 2015; 2 (1).

23. Abiodun O, Sotunsa J ,Ani F Jaiyesim E. Knowledge of HIV/AIDS and predictors of uptake of HIV counseling and testing among under graduate students of a privately-owned University in Nigeria. BMC Research Notes 2014; 7: 639.

24. Mwamwenda TS.African University Students' Knowledge of HIV/AIDS and knowledge transfer. J. AIDS HIV Res.2013; 5 (9): 341-346.

25. WHO. Barriers and facilitating factors in access to health services in the Republic of Moldova. Copenhagen, WHO Regional Office for Europe, 2012.

26. Ochako R, Ulwodi D, Njagi P, Kimetu S, Onyango A. Trends and determinants of comprehensive HIV and AIDS knowledge among urban young women in Kenya. AIDs Research and Therapy 2011; 8:11.

27. Sunday O, Akanni A, Adesegun F. Adolescents and HIV-related Behaviour in Nigeria. Does Knowledge of HIV/AIDs Promote Protective Sexual Behaviour among Sexually Active Adolescents? Paper presented at the 2012 Population Association of America Annual Meeting Program, San Francisco, California, May, 3-5, 2012

28. Asante KO, Oti-Boadi M. HIV/AIDS knowledge among undergraduate university students: implications for health education programs in Ghana. African Health Sciences 2013; 13(2): 270 - 277.

29. Faimau G, Maunganidze L, Tapera R, Mosomane L C.K , Apau S. Knowledge of HIV/AIDS, attitudes towards sexual risk behavior and perceived behavioral control among college students in Botswana. Cogent Social Sciences 2016; 2: 1164932.

30. Ekşi Z, Kömürcü N. Knowledge level of University students about sexually transmitted diseases/ Precedia-Social and behavioral sciences 2014; 122: 465-472.

31. Woldeyohannes D, Asmamaw Y, Sisay S, Hailesselassi W, Birmeta K, Tekeste Z. Risky HIV sexual behavior and utilization of voluntary counseling and HIV testing and associated factors among undergraduate students in AddisAbaba, Ethiopia. BMC Public Health 2017; 17:121.

32. Maraee AH, Elmoselhy HM, El-Gamel TA. Knowledge and attitude as regard sexual health among medical students of Menoufia University, Egypt. Menoufia Medical Journal 2016, 29:1085-1091.

33. Degroote S, Vogelaers D,Liefhooghe G, Vermeir P, Dominique Mandijck DM. Sexual experience and HIV-related knowledge among Belgian university students: a Questionnaire study. BMC Research Notes 2014; 7:3- 6.

34. Chen M, Liao Y, Liu J, Fang W, Hong N, Ye X, Li J,Tang Q, Pan W, Liao W. Comparison of sexual knowledge, attitude, and behavior between female Chinese college students from urban areas and rural areas: A hidden challenge for HIV/AIDS control in China. Hindawi Publishing Corporation, BioMed Research International Volume 2016, Article ID 8175921, 10 pages

35. Ayodele O, Ayodele OL. Urban-Rural differentials in HIV/AIDS knowledge of Nigerian senior secondary school students. International Journal of Health Sciences. September 2016; 4 (3): 35-41. 